\title{
ROMANIAN PRACTITIONNERS AND THE USE OF ESTIMATES IN ROMANIAN BUSINESS ENVIRONMENT
}

\author{
Nicoleta Farcane ${ }^{1}$, \\ Elena Iordache ${ }^{2}$, \\ Victoria Bogdan ${ }^{3}$
}

\begin{abstract}
Our research is based on a survey conducted among accountants, in order to investigate how the accounting profession feels in respect to the use of estimates at company level. By conducting this research we tried to obtain a realistic view on estimates applied in companies and on the degree of familiarity of Romanian accountants with estimation techniques, especially in the three representative fields at micro-level, namely: financials, accounting and auditing. We also intended to track down those fields of the estimation evaluation process where professionals face major challenges and to come up with solutions eventually.
\end{abstract}

Key words: accounting profession, estimations, evaluation, financial reporting.

JEL codes: $M 41$

\section{Introduction}

Many elements of the financial statements cannot be assessed accurately and, as such, are subject to estimates. Therefore, estimation techniques include: estimating the useful value of tangible and intangible assets in order to determine their recoverable amount and, hence their depreciation, estimating the residual value of tangible assets, estimating the useful life of assets, estimating the percentage of work in progress, estimating the value of various provisions for risks and expenses, estimating the adjustments for impairment of assets, etc.

In order to conduct an in-depth analysis of how Romanian professionals use accounting estimates, we reviewed the assessment and evaluation procedures used by chartered accountants, financial analysts and auditors. The main objective of our approach consists in reviewing and interpreting how different estimation techniques are used or interpreted in certain cases by the Romanian accountants.

This paper presents the research methodology used by the authors in analysing and investigating the practices based on estimation techniques, the results of the exploratory research and their interpretation. The last part of the article summarises and presents the conclusions of the conducted analysis and the future research to be undertaken.

In Romania, the body in charge with norms drawing up is the Office for Accounting Regulations within the Ministry of Finance with the consultation of the specialized professional bodies. The responsibilities of this organization as a direct interlocutor of EFRAG and, why not, of IASB - should include providing guidance for the IFRS implementation, monitoring the IFRS application, setting up working groups meant to identify issues significant to the implementation of the IFRS into the national business environment. CCRF supervises the IFRS implementation in Romania and the consistency with the European Directives. Also, the Romanian Ministry of Public

\footnotetext{
${ }^{1}$ West University, Faculty of Economics and Business Administration, Timisoara, Romania, nicoletafarcane@yahoo.fr

2 Academy of Economics Sciences, Consultant for the Mininstry of Finance, Bucharest, Romania, emilia.iordache@mfinante.gv.ro

${ }^{3}$ University of Oradea, Faculty of Economics Sciences, Oradea, Romania, vicbogdan@yahoo.com
} 
Finance has the authority to issue norms and regulations in the field of accounting, including the chart of accounts, financial statement samples and records to be produced and maintained.

The Body of Expert and Licensed Accountants of Romania (CECCAR) is the organization representing the Romanian accountancy profession, autonomous, non-governmental, non- profit and of public interest. CECCAR acts in determination for the understanding and application of International Financial Reporting Standards in order for the capital markets of Romania to have a high standard reporting in a European language.

The mission of the Chamber of Financial Auditors of Romania (CAFR) is to build on a solid ground, the identity and the public recognition of the financial audit profession in Romania, having as a main objective the sustainable development of the profession and its strengthening, in accordance with the Auditing Standards and with the Code of Ethics and professional conduct, by fully assimilating the International Standards on Auditing and the Code of Ethics issued by the International Federation of Accountants (IFAC), that will allow the Romanian financial auditors to provide high quality services, for the public interest, in general, and for the business community, in special.

In order to audit financial statements of certain types of companies, there are additional audit requirements established under the norms of each accounting regulatory body. Generally, the financial statements of the entities which meet the criteria size and prepare a full set of financial statements in accordance with OMPF 3055/2009 and the consolidated financial statements should be audited by authorized auditors.

The National Association of Romanian Evaluators - ANEVAR - was set up in 1992, as a professional, not for profit, non-governmental and independent organization, which acts in the public interest (fact supported by its acknowledgement as a public utility organization through $\mathrm{HG}$ (Government Decision) 1447/09.09.2004, and which promotes the valuation methods and techniques through specific means, in connection with the investors and the real estate transactions subject to the privatization process.

\section{Research methodology used in the analysis of assessment procedures at micro- economic level, based on estimation techniques}

We conducted an applied research. First we tested the conditions in which estimation techniques are used by companies in Romania and then we analysed the possibilities of assessing economic phenomena by means of estimates. To this end we prepared a study based on the statistical survey technique. According to this technique, we used a questionnaire addressed to professionals in following fields: financial-accounting, management and auditing. Based on the prepared questionnaire and by means of conducted investigations we obtained the perceptions of specialists in their capacity as representatives of the micro-economic level in relation to actual situations when estimation techniques are or are not used, the frequency and complexity of using estimates, information used in preparing the best estimates, the categories of persons who prepare estimates, the reasons for which estimates are not used in all circumstances, estimates of risk areas and materiality of disclosed information, estimates of fair value and financial position in financial statements and many other relevant issues related to the perception of Romanian practice in respect of using estimates in assessment actions, reporting and financial strategies at company level.

Because only accounting estimates are binding, especially when assessment of the financial position falls under the incidence of the prudence and cut-off/matching principles, in terms of studied population we made the following choices:

- chartered accountants (who also certify the financial statements);

- certified public accountants;

- financial auditors;

- members of the Board of Directors and managers. 
To extract a representative sample we tried to find the link between respondents and explored issues. Thus, we started from the idea that within an entity we have to come across accounting estimates first of all, which means that the most concerned people are those in accounting, financial and auditing departments. Since in an entity we also come across other categories of estimates (decisional, strategic, risk assessment), we considered that other categories of responsible persons should also be part of the sample (administrators, shareholders). We envisaged that the sample should represent a subset of the population identified above (experts, auditors, shareholders, administrators, etc.), containing its characteristics. The survey is mainly based in persons participating in professional training programmes organised in 2008-2009 by the Chamber of Financial Auditors, the Finance Ministry and other private companies specialised in professional training activities for adults in auditing, accounting and tax.

The sample was made up of professionals working in large, small and medium-sized companies.

The sample included a number of 196 persons, and the survey results are guaranteed with a probability of 0.95 , with an error margin of $\pm 7 \%$. The sample's structure is shown in Figure 1 .

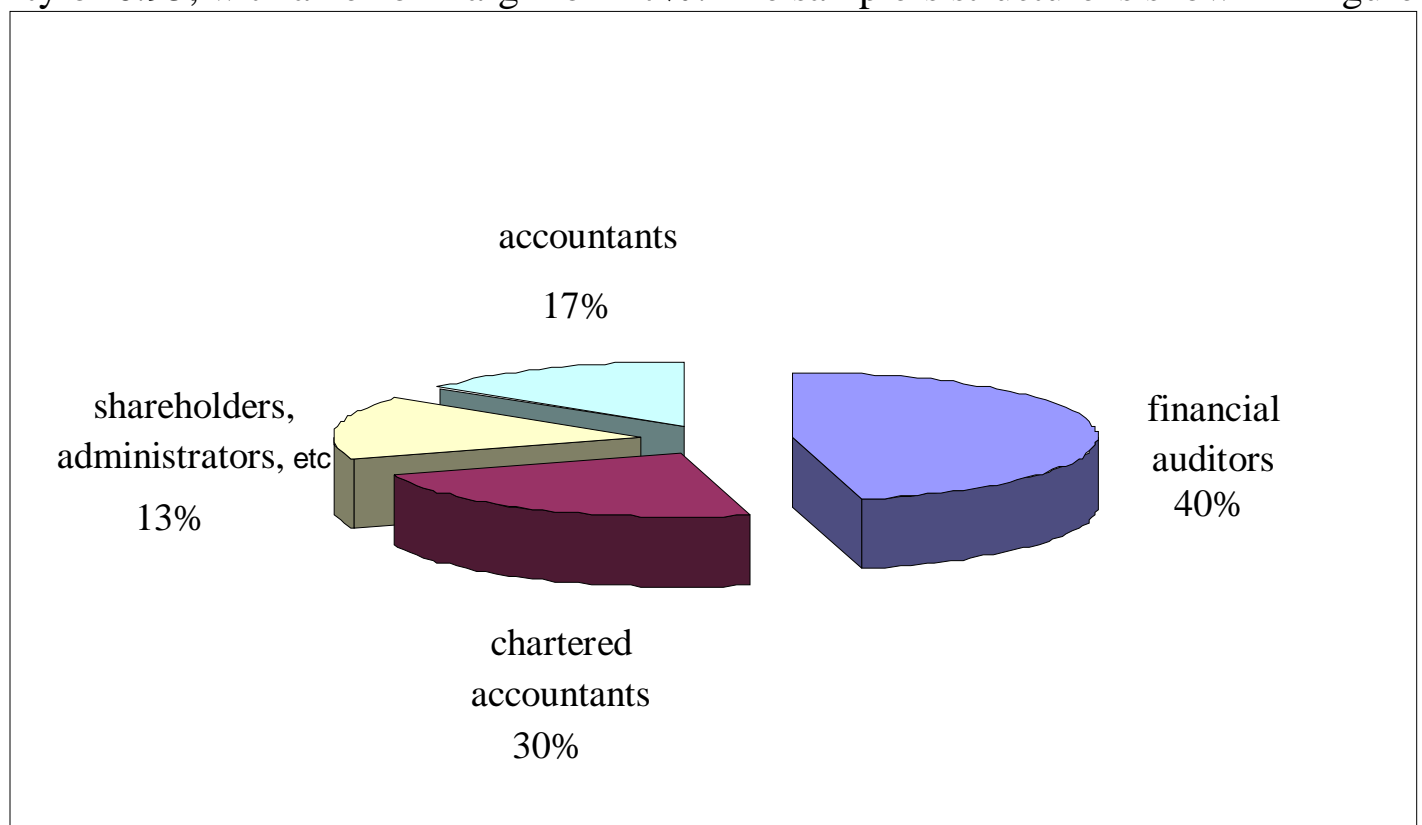

Fig. no. 1 - Structure of the sample

In preparing the questionnaire we aimed to have simple and concise questions, easy to understand, without interpretations, focused on the respondent's experience and knowledge. In terms of questionnaire structure, we aimed to use a variety of questions related to assessment procedures, such as: introductory questions, transition questions, filter questions, bifurcated questions, control questions, identification questions, etc. The questionnaires were distributed through a direct approach, by means of professional training programmes, aiming for the survey to include professionals from the whole country and not only from a certain territorial area. Thus, out of the 300 distributed questionnaires, we received answers from a number of 196 persons, resulting in a response rate of $65 \%$.

Data processing aimed to obtain information for the single-varied data analysis, particularly the distribution of absolute and relative frequencies (percentages) for all variables in the questionnaire and preparation of charts adapted to each processing type. 


\section{Research results and their interpretation}

Our investigation emphasised those situations where estimation assessments are required by law (e.g. impairment, provisions, fair value, useful life of depreciable assets, etc) or derive implicitly from economic practices (estimation of income and expenses budgets).

Question no. 1: In which of the following assessment situations do you use the "estimation technique"?

Table no. 1

\section{Use of estimations techniques for the assessment}

\begin{tabular}{|c|c|c|c|c|c|}
\hline & Denomination & Yes & No & $\begin{array}{c}\text { Not } \\
\text { expres } \\
\text { S }\end{array}$ & $\begin{array}{c}\text { Total } \\
(\%)\end{array}$ \\
\hline $\mathrm{A}$ & Valuation of tangible assets at fair value & 53,45 & 32,76 & 13,79 & 100 \\
\hline $\mathrm{B}$ & $\begin{array}{l}\text { Assessment of losses from impairment of } \\
\text { assets (losses related to tangible assets, } \\
\text { intangible assets, receivables, cash, etc) }\end{array}$ & 67,24 & 12,07 & 20,69 & 100 \\
\hline $\mathrm{C}$ & $\begin{array}{l}\text { Assessment of provisions for risks and } \\
\text { expenses } \\
\text { (provisions for litigation, performance bonds, } \\
\text { restructuring, taxes, etc) }\end{array}$ & 75,86 & 13,79 & 10,34 & 100 \\
\hline $\mathrm{D}$ & $\begin{array}{l}\text { Assessment of useful lives for tangible and } \\
\text { intangible assets }\end{array}$ & 50,00 & 32,76 & 17,24 & 100 \\
\hline $\mathrm{E}$ & $\begin{array}{l}\text { Assessment of net realisable value of } \\
\text { inventories presented in the balance sheet }\end{array}$ & 32,76 & 36,21 & 31,03 & 100 \\
\hline $\mathrm{F}$ & $\begin{array}{l}\text { Revenues and expenses at balance sheet date } \\
\text { are assessed based on the cut-off principle }\end{array}$ & 18,97 & 53,45 & 27,59 & 100 \\
\hline
\end{tabular}

The results of the study (table 1) show there are also respondents who are not aware of such evaluation techniques.

Another interesting finding relates to the fact that respondents are not concerned of complying with the cut-off principle in terms of revenues and expenses estimates. More than half of the respondents (53.45\%) accept they do not do such estimates. A fairly large percentage of $27.59 \%$ are not aware of the necessity or legality of such estimates, and those who are concerned about this kind of estimation cover a very small percentage (18.97\%).

Assessment of provisions for risks and expenses Assessment of losses related to impairment of assets Valuation of tangible assets at fair value

Assesement of useful lives Assessment of net realisable value for inventories

Revenues and expenses estimated at balance sheet date Other situations

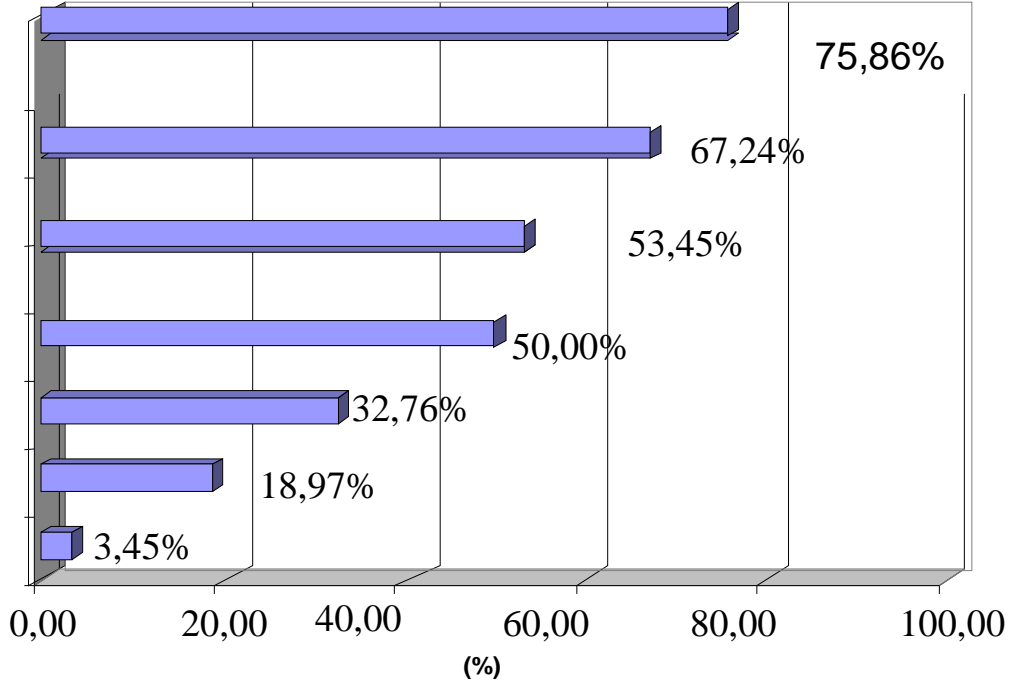

(\%)

Fig. no. 2 - Circumstances in which the estimation techniques are used 
One reason for which some estimates are more used than others would also consist in the fact that some of these are recognised fiscally (provisions for risks and expenses).

We note that the estimation techniques are most used and applied by financial auditors.

Question no. 2:

Table no. 2

Use of estimation techniques based on the respondents' capacity

\begin{tabular}{|l|c|c|c|c|}
\hline \multicolumn{1}{|c|}{ Denomination } & $\begin{array}{c}\text { Financial } \\
\text { auditor }\end{array}$ & $\begin{array}{c}\text { Apprentice/ } \\
\text { expert/ } \\
\text { economist }\end{array}$ & $\begin{array}{c}\text { Administrator, } \\
\text { shareholder/ } \\
\text { Other categories }\end{array}$ & $\begin{array}{c}\text { Total } \\
\text { (\%) }\end{array}$ \\
\hline $\begin{array}{l}\text { Valuation of tangible assets at fair } \\
\text { value }\end{array}$ & 65,52 & 16,13 & 19,35 & $\mathbf{1 0 0}$ \\
\hline $\begin{array}{l}\text { Assessment of losses from } \\
\text { impairment of assets (losses related } \\
\text { to tangible assets, intangible assets, } \\
\text { receivables, cash, etc) }\end{array}$ & 71,79 & 17,95 & 10,26 & $\mathbf{1 0 0}$ \\
\hline $\begin{array}{l}\text { Assessment of provisions for risks } \\
\text { and expenses (provisions for } \\
\text { litigation, performance bonds, } \\
\text { restructuring, taxes, etc) }\end{array}$ & 72,73 & 18,18 & 9,09 & $\mathbf{1 0 0}$ \\
\hline $\begin{array}{l}\text { Assessment of useful lives for } \\
\text { tangible and intangible assets }\end{array}$ & 75,86 & 17,24 & 6,90 & $\mathbf{1 0 0}$ \\
\hline $\begin{array}{l}\text { Assessment of net realisable value } \\
\text { of inventories presented in the } \\
\text { balance sheet }\end{array}$ & 84,21 & 5,6 & 10,53 & $\mathbf{1 0 0}$ \\
\hline $\begin{array}{l}\text { Revenues and expenses at balance } \\
\text { sheet date are assessed based on } \\
\text { the cut-off principle }\end{array}$ & 54,55 & 18,18 & 27,27 & $\mathbf{1 0 0}$ \\
\hline
\end{tabular}

An explanation for the accountants' lack of interest could consist in the fact that accounting departments aim for the accounting reports to be as close to the tax reports as possible, because most companies in Romania are small and medium-sized companies, which are not subject to audits, and shareholders pursue an accounting result based on cash principles and not on accruals and on-going concern concepts.

In order to present a credible financial position in the year-end financial statements at year-end, do you assess by means of estimation both the provisions for risks and expenses and the losses from impairment of assets?

Table no. 3

Use of estimations for the provisions and for impairment of assets

\begin{tabular}{|c|l|c|c|c|c|}
\hline & \multicolumn{1}{|c|}{ Possible situation } & Yes & No & $\begin{array}{c}\text { I don't } \\
\text { know }\end{array}$ & $\begin{array}{c}\text { Tot } \\
\text { al } \\
(\%)\end{array}$ \\
\hline A & Only in some cases (partially) & 51,72 & 18,97 & 29,31 & $\mathbf{1 0 0}$ \\
\hline B & $\begin{array}{l}\text { They are assessed in each situation according } \\
\text { to the economic reality }\end{array}$ & 28,16 & 40,00 & 31,84 & $\mathbf{1 0 0}$ \\
\hline C & Only the tax deductible ones are assessed & 23,79 & 26,21 & 50,00 & $\mathbf{1 0 0}$ \\
\hline D & $\begin{array}{l}\text { They are not assessed, as these evaluations } \\
\text { decrease profits or increase accounting losses }\end{array}$ & 31,72 & 11,03 & 57,25 & $\mathbf{1 0 0}$ \\
\hline
\end{tabular}




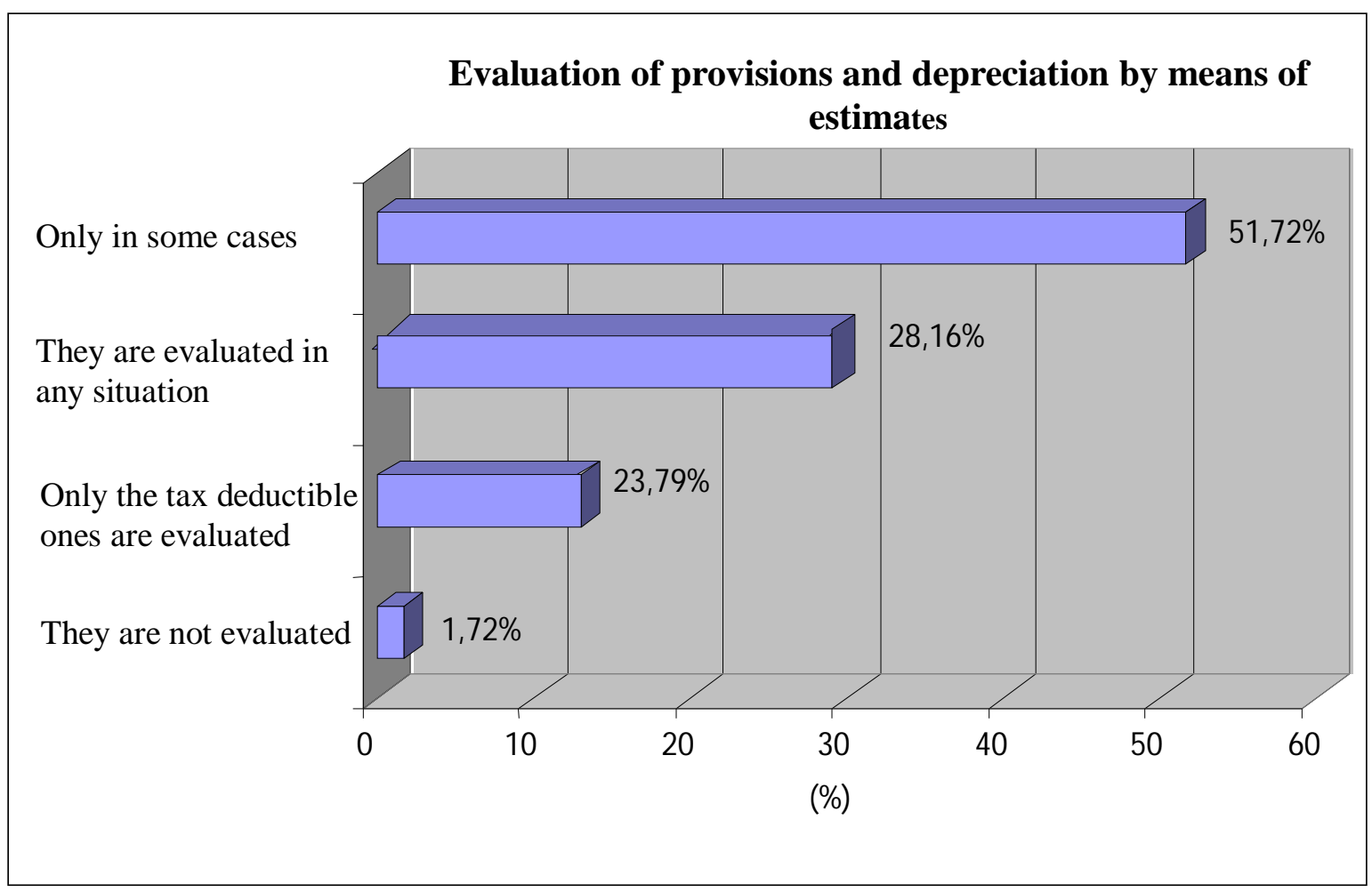

Fig. no. 3 - Evaluation of provisions and depreciation by means of estimates

These results show a certain subjectivism, as half of the respondents accept they do not do such estimates in all situations. From the previous question we noted that the two types of estimates are performed more by auditors and less by accountants. According to law, estimates should be made regardless of their effects on the company's financial results. However, we observe that a considerable percentage of respondents (32\%) accept they estimate provisions and depreciation according to their effects on results.

Question no. 3:

Do you use estimation techniques in determining useful lives of tangible and intangible assets?

Use of estimation techniques in determining useful lives of assets

Table no. 4

\begin{tabular}{|l|l|}
\hline & $(\%)$ \\
\hline Yes & 55,17 \\
\hline No & 29,31 \\
\hline No answer & 15,52 \\
\hline Total & $\mathbf{1 0 0 , 0 0}$ \\
\hline
\end{tabular}

First we tested the credibility of the answer given to the first question (d) and then we split the respondents in two categories (those who estimate the useful lives and those who do not estimate them).

The structure of respondents according to the given answer is presented graphically as following (figure 4): 


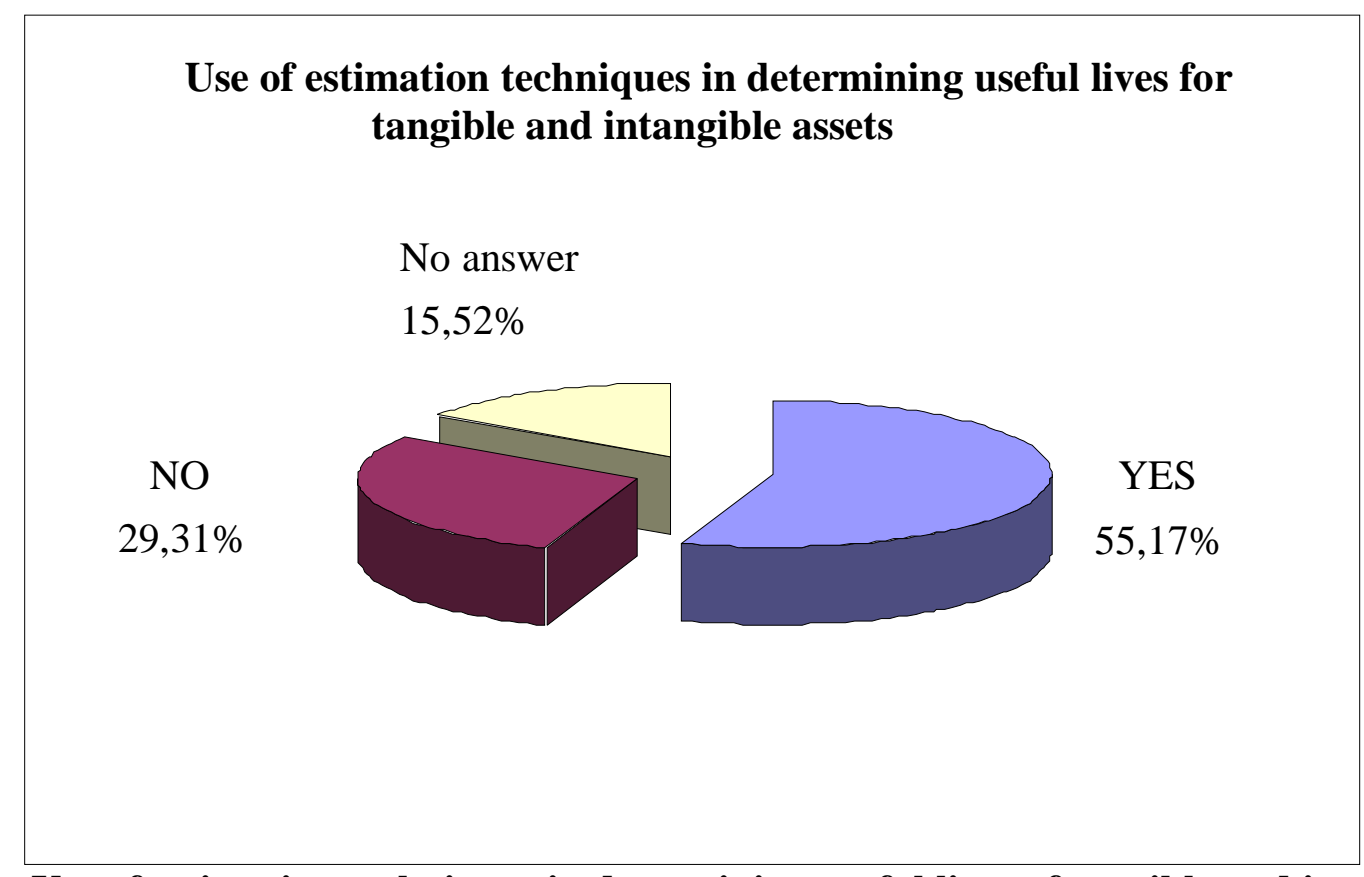

Fig. no. 4 - Use of estimation techniques in determining useful lives of tangible and intangible assets

Table no. 5

Use of estimation techniques in determining useful lives of tangible and intangible assets based on respondents' capacity

\begin{tabular}{|l|c|c|c|}
\hline $\begin{array}{c}\text { Do you use estimates technique in } \\
\text { determining useful lives of tangible and } \\
\text { intangible assets? }\end{array}$ & $\begin{array}{c}\text { Financi } \\
\text { al } \\
\text { auditor }\end{array}$ & $\begin{array}{c}\text { Apprentice/ } \\
\text { expert/ } \\
\text { economist }\end{array}$ & $\begin{array}{c}\text { Administrator, } \\
\text { shareholder/ } \\
\text { Other } \\
\text { categories }\end{array}$ \\
\hline Yes & 56,10 & 55,56 & 50,00 \\
\hline No & 29,27 & 33,33 & 25,00 \\
\hline I don't know / No answer & 14,63 & 11,11 & 25,00 \\
\hline Total & $\mathbf{1 0 0 , 0 0}$ & $\mathbf{1 0 0 , 0 0}$ & $\mathbf{1 0 0 , 0 0}$ \\
\hline
\end{tabular}
negative).

Furthermore, question no. 3 is split on the two categories of answers (affirmative and

Question no. 3.1

If "YES" which of the following models/information do you use?

Table no. 6

Use of models/information

\begin{tabular}{|l|l|c|c|c|c|}
\hline \multicolumn{1}{|c|}{ Denomination } & Yes & No & $\begin{array}{c}\text { I } \\
\text { don't } \\
\text { know }\end{array}$ & $\begin{array}{c}\text { Total } \\
(\%)\end{array}$ \\
\hline A & Good practice models & 28,12 & 3,13 & 68,75 & $\mathbf{1 0 0 , 0 0}$ \\
\hline B & $\begin{array}{l}\text { Lifetime used in the group (if the company } \\
\text { is part of a group) }\end{array}$ & 31,25 & 18,75 & 50,00 & $\mathbf{1 0 0 , 0 0}$ \\
\hline C & Models developed inside the company & 46,87 & 6,26 & 46,87 & $\mathbf{1 0 0 , 0 0}$ \\
\hline D & Assistance provided by specialists & 59,37 & 9,38 & 31,25 & $\mathbf{1 0 0 , 0 0}$ \\
\hline E & Other methods & 6,25 & 6,25 & 87,50 & $\mathbf{1 0 0 , 0 0}$ \\
\hline
\end{tabular}


Most of the respondents (over 59\%) use estimation techniques in determining useful lives for tangible and intangible assets with specialist assistance, and only $47 \%$ use methods developed inside the company (table 3.6). The other estimation models indicated in the questionnaire are used in a low percentage.

These results raised some doubts about understanding estimations used for the useful life of a depreciable asset. Over time, for many professionals accounting lifetimes were equal with normal lifetimes recognised for tax purposes, which means that most practitioners do not make efforts to distinguish the two lifetimes, respectively accounting and fiscal lifetimes.

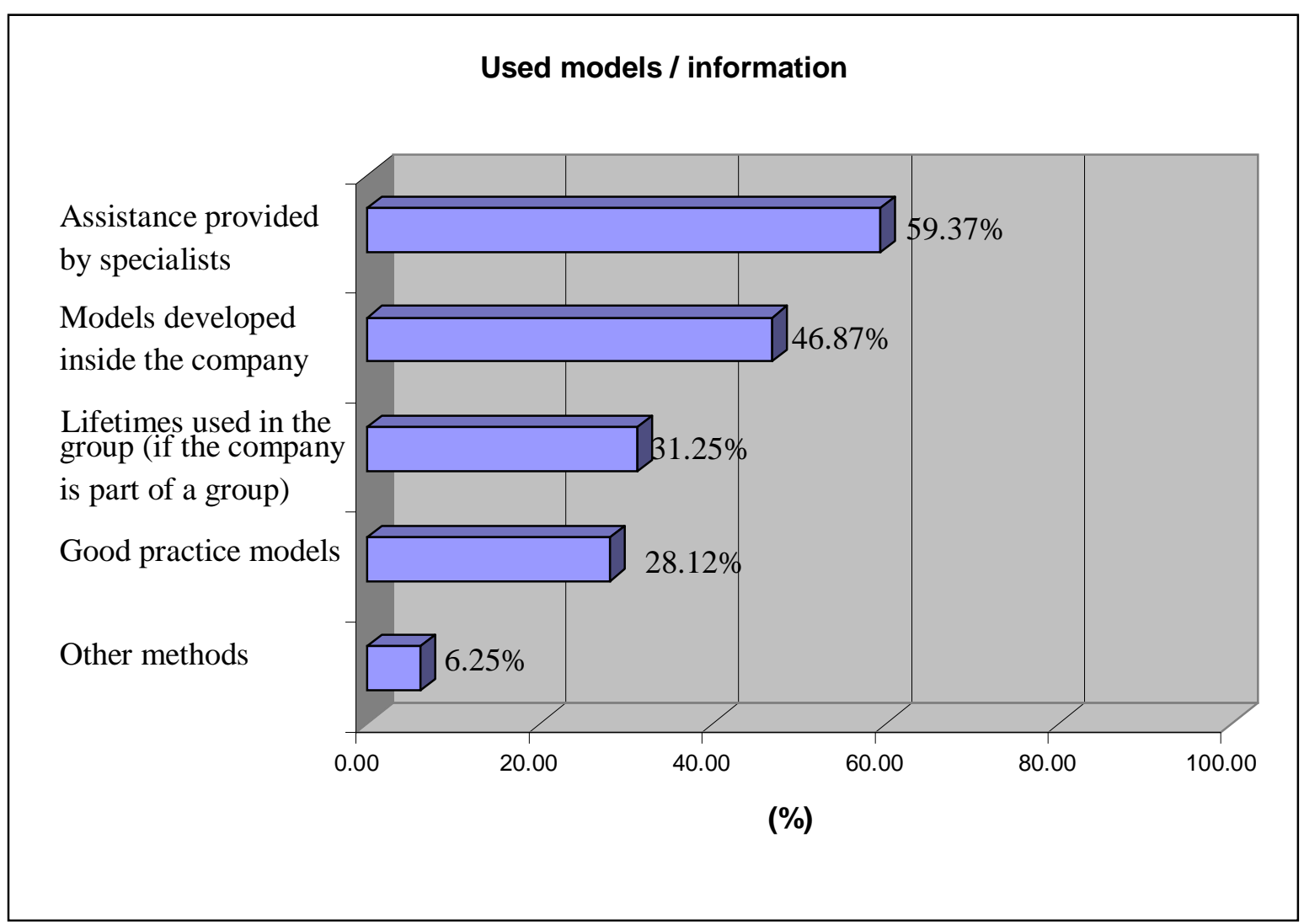

Fig. no. 5 - Models and information used for estimating useful lives

Approximately $60 \%$ of those respondents who estimate lifetimes receive specialist assistance, relying on specialists' experience and not on their own experience, as it would have been normal.

Question no. 3.2 If "NO", can you explain which of the below situations is suitable for you?

Situations suitable

\begin{tabular}{|c|c|c|c|c|c|}
\hline & Denomination & Yes & No & $\begin{array}{l}\text { I don't } \\
\text { know }\end{array}$ & $\begin{array}{l}\text { Total } \\
(\%)\end{array}$ \\
\hline A & We use lifetimes permitted for tax purposes & 76,48 & 23,52 & 0,00 & 100,00 \\
\hline B & $\begin{array}{l}\text { Development of own estimation models } \\
\text { generates considerable costs for the } \\
\text { company }\end{array}$ & 23,52 & 47,07 & 29,41 & 100,00 \\
\hline $\mathrm{C}$ & We do not have specialists & 29,41 & 41,18 & 29,41 & $\mathbf{1 0 0 , 0 0}$ \\
\hline $\mathrm{D}$ & $\begin{array}{l}\text { Tangible and intangible assets are } \\
\text { immaterial for the company's patrimony }\end{array}$ & 23,52 & 35,30 & 41,18 & $\mathbf{1 0 0 , 0 0}$ \\
\hline
\end{tabular}




\begin{tabular}{|c|l|c|c|c|c|}
\hline $\mathrm{E}$ & $\begin{array}{l}\text { They generate non-deductible expenses for } \\
\text { tax purposes }\end{array}$ & 23,52 & 29,41 & 47,07 & $\mathbf{1 0 0 , 0 0}$ \\
\hline $\mathrm{F}$ & We are not interested in such estimates & 11,77 & 29,41 & 58,82 & $\mathbf{1 0 0 , 0 0}$ \\
\hline
\end{tabular}

Of the respondents who do not use estimation techniques (50\%), a percentage of $76.48 \%$ accepts they actually use fiscal lifetimes and do not estimate useful lives of tangible and intangible assets out of economic reasons (table 3.7). By corroborating the two categories of responses, both the affirmative and the negative ones, we observe that respondents either do not know the concept of estimating the useful life of tangible assets (in both variants the answer "I don't know" is very frequent), or they use the known practices, such as the tax ones.

\section{Reasons why estimation techniques are not used}

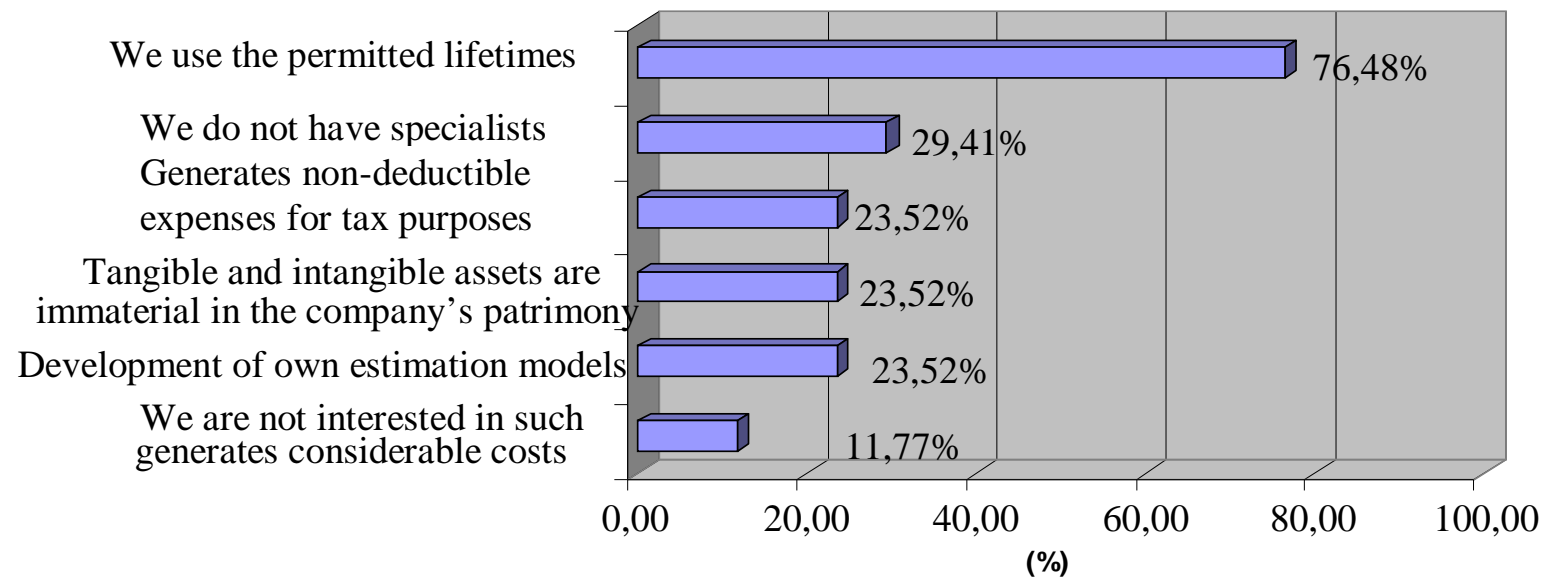

Fig. no. 6 - Reasons why estimation techniques are not used in estimating useful lives of depreciable assets

In the questionnaire respondents explain that estimation efforts seem useless as long as fiscal lifetimes can be determined within a range of durations.

\section{Question no. 4}

When preparing the revenues and expenses budgets do you use information obtained by means of estimation techniques based on:

Table 8

The use of estimation techniques for the budgets

\begin{tabular}{|l|l|c|c|c|c|}
\hline & \multicolumn{1}{|c|}{ Denomination of evaluation technique } & Yes & No & $\begin{array}{c}\text { I } \\
\text { don't } \\
\text { know }\end{array}$ & $\begin{array}{c}\text { Total } \\
(\%)\end{array}$ \\
\hline A & Inflation index & 60,34 & 8,62 & 31,03 & $\mathbf{1 0 0 , 0 0}$ \\
\hline B & $\begin{array}{l}\text { Revenues and expenses adjustments based on } \\
\text { adjustment rates }\end{array}$ & 51,72 & 10,34 & 37,93 & $\mathbf{1 0 0 , 0 0}$ \\
\hline C & Risk assessment and on-going concern & 72,41 & 5,17 & 22,41 & $\mathbf{1 0 0 , 0 0}$ \\
\hline D & Others & 5,17 & 5,17 & 89,66 & $\mathbf{1 0 0 , 0 0}$ \\
\hline
\end{tabular}

Most respondents (over 72\%) first base their evaluation of revenues and expenses in budgets on risk assessment and on-going concern, and only secondly on inflation indices (60.34\%). 


\section{Techniques used for estimating fair value}

The question aims firstly to assess the frequency of using evaluation at fair value, but also what kind of reasoning is used when such an evaluation is chosen.

\section{Question no. 5}

Which techniques / information below do you use for estimating fair value?

Table no. 9

Use the techniques for estimating fair value

\begin{tabular}{|c|c|c|c|c|c|}
\hline & Denomination & Yes & No & $\begin{array}{c}\text { I } \\
\text { don't } \\
\text { know }\end{array}$ & $\begin{array}{l}\text { Total } \\
(\%)\end{array}$ \\
\hline $\mathrm{A}$ & $\begin{array}{l}\text { Tangible assets } \\
\text {-market value } \\
\text {-replacement cost } \\
\text {-adjustment to inflation } \\
\text {-adjustment of future economic flows } \\
\text {-others }\end{array}$ & $\begin{array}{l}81,03 \\
36,20 \\
18,97 \\
34,48 \\
12,06\end{array}$ & $\begin{array}{c}3,45 \\
17,25 \\
25,86 \\
15,52 \\
5,17\end{array}$ & $\begin{array}{l}15,52 \\
46,55 \\
55,17 \\
50,00 \\
82,77\end{array}$ & $\begin{array}{l}100,00 \\
100,00 \\
100,00 \\
100,00 \\
100,00\end{array}$ \\
\hline B & $\begin{array}{l}\text { Evaluation of financial instruments in } \\
\text { consolidated financial statements }\end{array}$ & 29,31 & 6,90 & 63,79 & 100,00 \\
\hline $\mathrm{C}$ & $\begin{array}{l}\text { Goods received free of charge } \\
\text { - market value } \\
\text { - replacement cost } \\
\text { - others }\end{array}$ & $\begin{array}{c}70,69 \\
15,52 \\
0,00\end{array}$ & $\begin{array}{c}5,17 \\
15,52 \\
1,72\end{array}$ & $\begin{array}{l}24,14 \\
68,96 \\
98,28\end{array}$ & $\begin{array}{l}100,00 \\
100,00 \\
100,00\end{array}$ \\
\hline
\end{tabular}

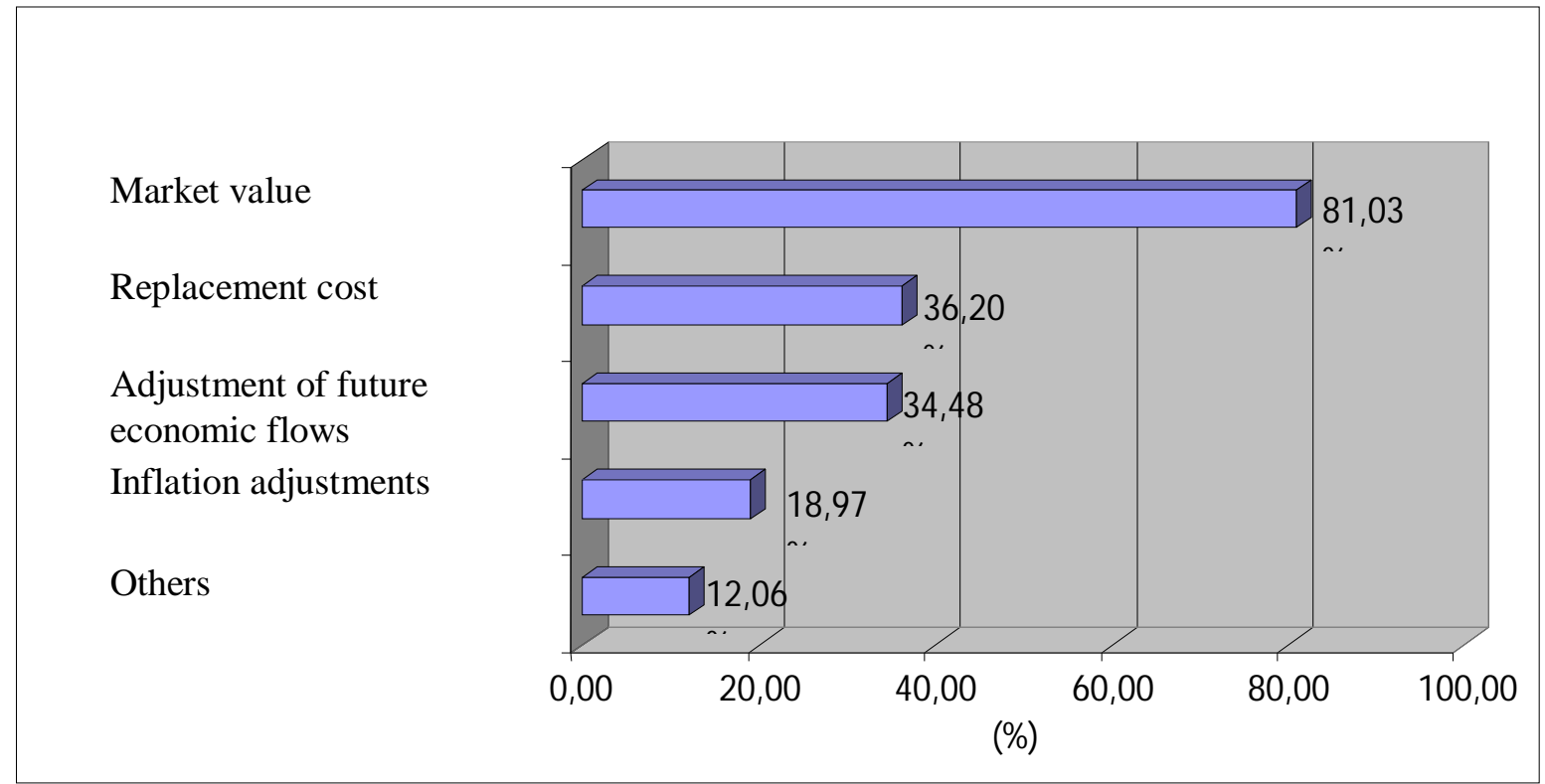

Fig. no. 7 - Techniques used for estimating fair value of tangible assets

\section{Assessment of risks}

At management level there is a clear need for knowledge of risk factors that influence the environment in which each activity is developed, but their assessment is much more useful for entrepreneurs. 
Thus, according to accounting regulations consistent with European Directives, the report of the administrator that accompanies the financial statements has to disclose the company's objectives and policies in respect to financial risk management, including its hedging policy against risks for each major type of forecasted transactions.

Question no. 6

In your activity do you assess / estimate the risks you face? For which of the following risks do you do assessments to protect yourself against them?

Table no. 10

Use the assessments to protect against risks

\begin{tabular}{|l|l|c|c|c|c|}
\hline \multicolumn{1}{|c|}{ Denomination } & Yes & No & $\begin{array}{c}\text { I don't } \\
\text { know }\end{array}$ & Total (\%) \\
\hline A & Market risk & 65,52 & 6,90 & 27,58 & $\mathbf{1 0 0 , 0 0}$ \\
\hline B & Price risk & 41,38 & 12,07 & 46,55 & $\mathbf{1 0 0 , 0 0}$ \\
\hline C & Credit risk & 39,66 & 15,52 & 44,82 & $\mathbf{1 0 0 , 0 0}$ \\
\hline D & Liquidity risk & 56,90 & 12,07 & 31,03 & $\mathbf{1 0 0 , 0 0}$ \\
\hline E & $\begin{array}{l}\text { Interest rate risk for cash } \\
\text { flow }\end{array}$ & 36,21 & 10,34 & 53,45 & $\mathbf{1 0 0 , 0 0}$ \\
\hline F & Other risks & 8,62 & 5,17 & 86,21 & $\mathbf{1 0 0 , 0 0}$ \\
\hline
\end{tabular}

Of the risks mentioned above (table 10) $65 \%$ of the respondents indicated they are most concerned of the market risk. Given also the percentages obtained (approximately 40\%) for the other categories of risks (price risk, credit risk, interest rate risk), we draw the conclusion that Romanian companies are concerned with risk assessment.

In our opinion this reaction of practitioners related to risk assessment is justified in correlation with the characteristics of the Romanian business environment (inflation periods, low purchasing power, reduced exports, high imports, productive economic branches are less developed than consumer branches, investments develop at a slower rhythm, high tax burden, high unemployment, lack of specialists, underdeveloped capital market, lack of active markets, high interest rate, lack of government incentives for development of small and medium-sized companies, limited number of foreign investments, etc).

The risks hierarchy obtained further to processing the answers from respondents is presented graphically as follows (figure 8): 


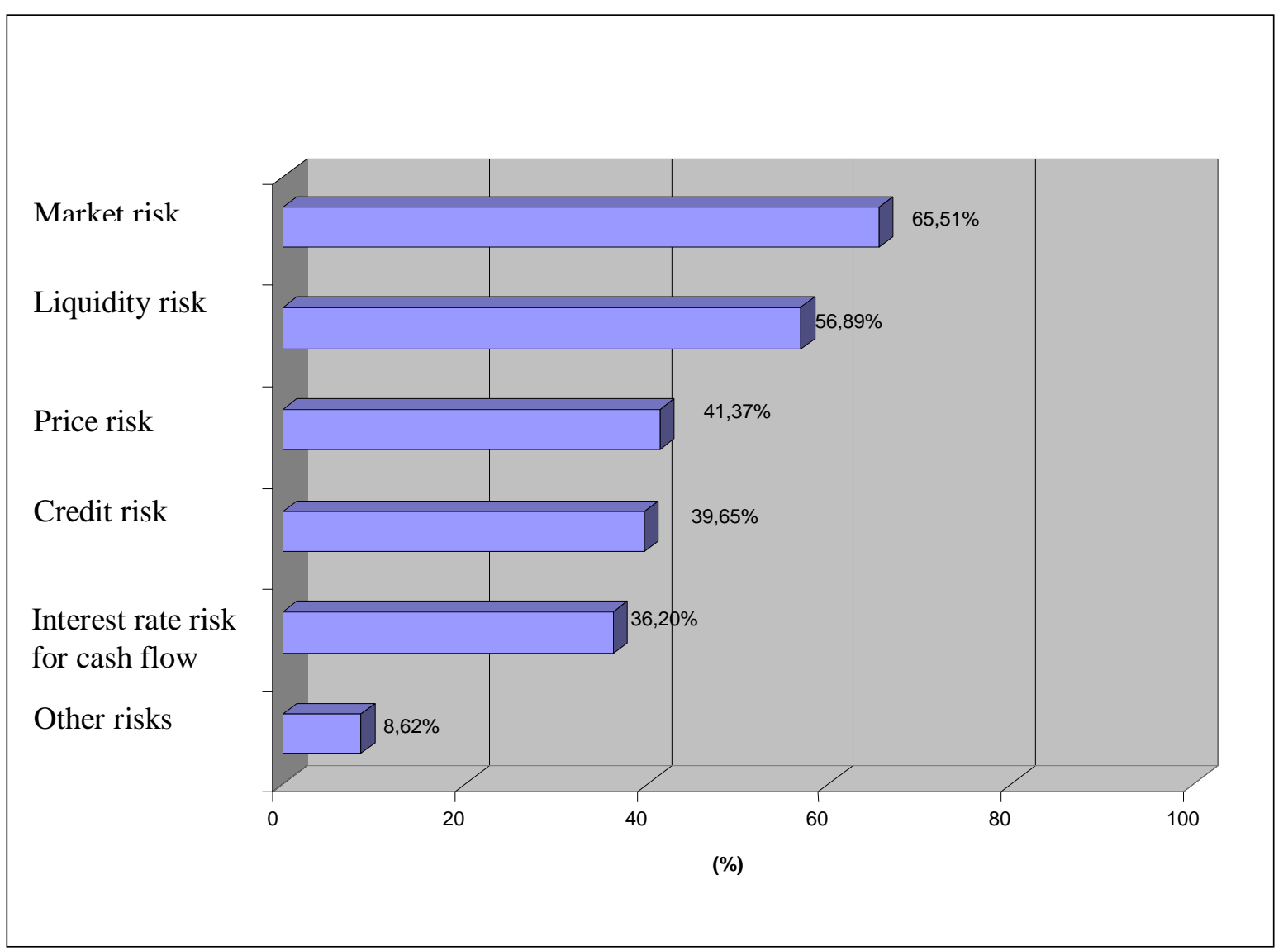

Fig. no. 8 - Risk assessment / evaluation

According to the respondents' professional capacity (table 3.11), we note that auditors are most interested in risk assessment.

Table no. 11

Risks assessed based on respondents' capacity

\begin{tabular}{|l|c|c|c|c|}
\hline $\begin{array}{c}\text { For which of the following risks do } \\
\text { you do assessments to protect } \\
\text { yourself against them? }\end{array}$ & $\begin{array}{c}\text { Financi } \\
\text { al } \\
\text { auditor }\end{array}$ & $\begin{array}{c}\text { Apprentic } \\
\text { e / expert } \\
\text { / } \\
\text { economist }\end{array}$ & $\begin{array}{c}\text { Administrator, } \\
\text { shareholder/ } \\
\text { Other } \\
\text { categories }\end{array}$ & $\begin{array}{c}\text { Total } \\
(\%)\end{array}$ \\
\hline Market risk & 71,05 & 18,42 & 10,53 & $\mathbf{1 0 0 , 0 0}$ \\
\hline Price risk & 75,00 & 12,50 & 12,50 & $\mathbf{1 0 0 , 0 0}$ \\
\hline Credit risk & 82,61 & 8,70 & 8,70 & $\mathbf{1 0 0 , 0 0}$ \\
\hline Liquidity risk & 75,76 & 18,18 & 6,06 & $\mathbf{1 0 0 , 0 0}$ \\
\hline Interest rate risk for cash flow & 76,19 & 23,81 & 0,00 & $\mathbf{1 0 0 , 0 0}$ \\
\hline
\end{tabular}

Basis of financial decisions and preparation of financial-accounting estimates Question no. 7

Yours financial decisions are made based on empirical methods or on estimation methods? 
Financial decisions and empirical or estimation methods

\begin{tabular}{|l|l|c|c|}
\hline & \multicolumn{1}{|c|}{$\begin{array}{c}\text { Denomination of financial } \\
\text { decision }\end{array}$} & $\begin{array}{c}\text { Empirical } \\
\text { methods used } \\
\text { (without } \\
\text { estimates) } \\
(\boldsymbol{\%})\end{array}$ & $\begin{array}{c}\text { Estimation methods } \\
\text { (feasibility studies, } \\
\text { business plan, updated } \\
\text { values etc.) } \\
(\%)\end{array}$ \\
\hline A & $\begin{array}{l}\text { Investment decisions } \\
\text { (acquisition, construction of assets, } \\
\text { business development) }\end{array}$ & 6.90 & 75.86 \\
\hline B & $\begin{array}{l}\text { Financing decisions } \\
\text { (loans, joint ventures, etc) }\end{array}$ & 5.17 & 68.97 \\
\hline C & $\begin{array}{l}\text { Dividend decisions } \\
\text { (distribution of dividends) }\end{array}$ & 20.69 & 29.31 \\
\hline D & Other financial decisions & 3.45 & 6.90 \\
\hline
\end{tabular}

Based on the responses (table 12) we note that for most respondents the rule consists in basing the financial decisions on estimates, although these methods are more costly than the empirical ones, but also more relevant.

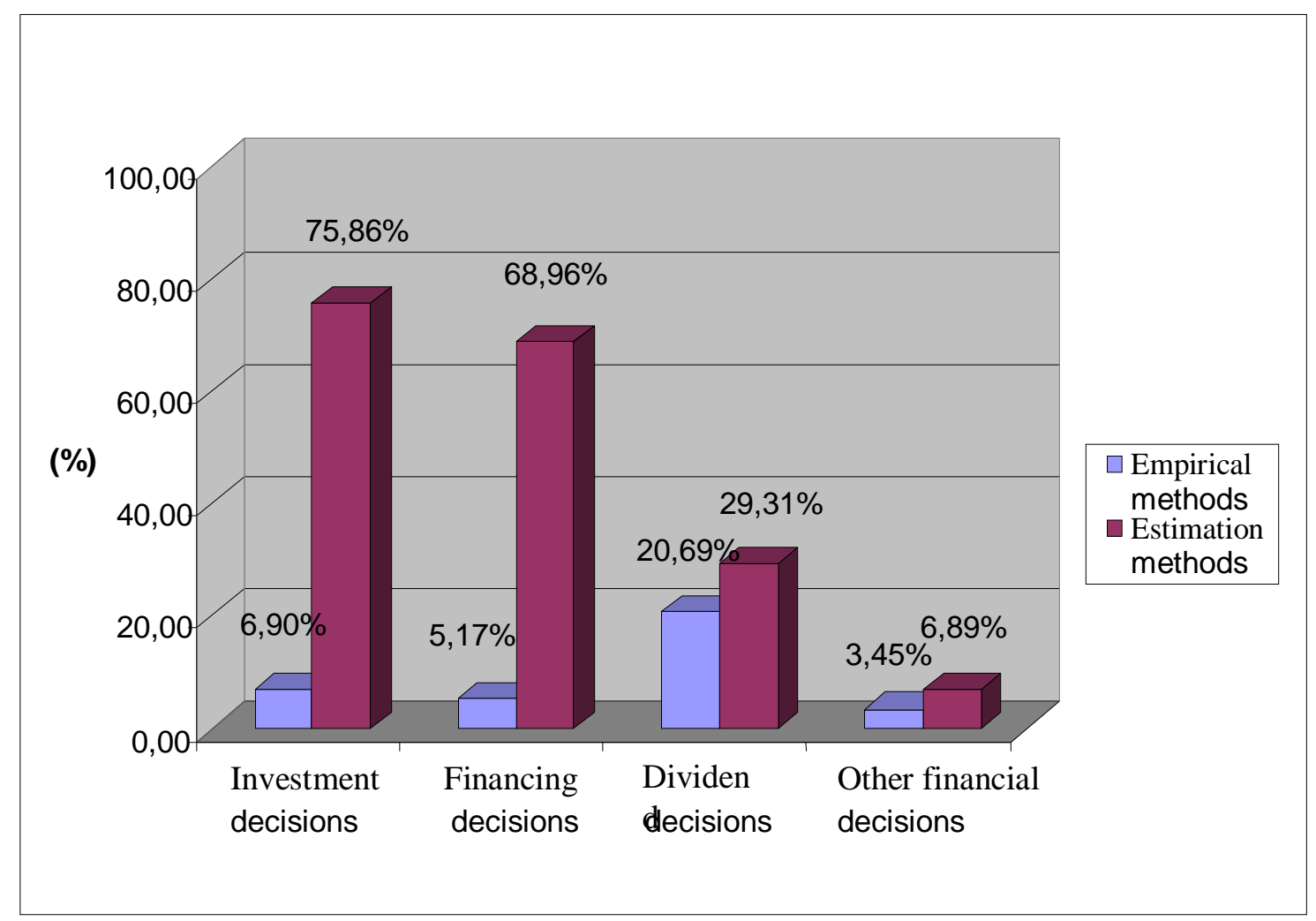

Fig. no.9 - Situations of using empirical or estimation methods

Based on the results disclosed in the chart, in our opinion dividend distribution does not necessarily represent a financial policy, but rather a decision taken by the shareholder at a certain moment depending on the company's liquidities. 


\section{Question no. 8}

How do you do accounting and financial estimates?

Table no. 13

How estimates are made

\begin{tabular}{|l|l|c|c|c|c|}
\hline & \multicolumn{1}{|c|}{ Denomination } & Yes & No & $\begin{array}{c}\text { I don't } \\
\text { know }\end{array}$ & $\begin{array}{c}\text { Total } \\
(\%)\end{array}$ \\
\hline A & Through own efforts & 43,10 & 1,73 & 55,17 & $\mathbf{1 0 0 , 0 0}$ \\
\hline B & With assistance provided by specialists & 67,24 & 0,00 & 32,76 & $\mathbf{1 0 0 , 0 0}$ \\
\hline C & We do not do estimates & 0,00 & 0,00 & 100,00 & $\mathbf{1 0 0 , 0 0}$ \\
\hline
\end{tabular}

The responses received (table 13) show that estimates are made with the assistance of specialists (67\%), which means that Romanian companies do not have enough experience or potential to make all these estimates, but still there are entities that do estimates through their own efforts $(43 \%)$.

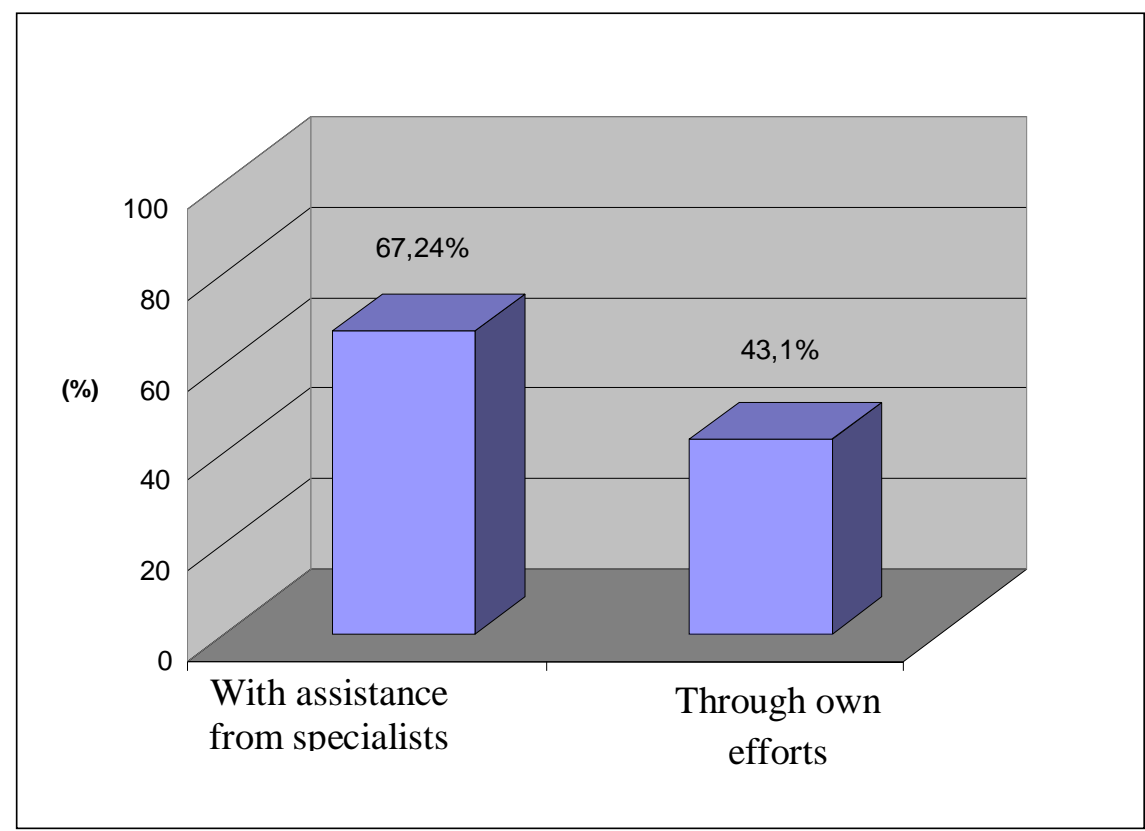

Fig. no. 10 - Preparation of financial-accounting estimates

Table no. 14

Preparation of financial-accounting estimates according to respondents' capacity

\begin{tabular}{|l|c|c|c|c|}
\hline $\begin{array}{c}\text { How do you do accounting and } \\
\text { financial estimates? }\end{array}$ & $\begin{array}{c}\text { Financi } \\
\text { al } \\
\text { auditor }\end{array}$ & $\begin{array}{c}\text { Apprentice } \\
\text { / expert / } \\
\text { economist }\end{array}$ & $\begin{array}{c}\text { Administrato } \\
\text { r, } \\
\text { shareholder/ } \\
\text { Other } \\
\text { categories }\end{array}$ & $\begin{array}{c}\text { Total } \\
(\%)\end{array}$ \\
\hline Through own efforts provided by & 79,49 & 15,38 & 5,13 & $\mathbf{1 0 0 , 0 0}$ \\
\hline $\begin{array}{l}\text { With assistance propo } \\
\text { specialists }\end{array}$ & 20,00 & 80,00 & 0,00 & $\mathbf{1 0 0 , 0 0}$ \\
\hline
\end{tabular}

In terms of sample structure, we note that professionals employed in the financial field call to specialists most, while auditors make those estimates themselves. 
Methods for determining materiality thresholds in accounting and auditing

Questions raised in this case aimed to identify the methods used to estimate materiality thresholds and especially if companies have methodologies to estimate the materiality thresholds.

\section{Question no. 9}

Disclosure of information in the financial statements is made based on estimation of materiality threshold (compliance with materiality threshold principle). What methods do you use to estimate these thresholds?

Table no. 15

Use of methods to estimate thresholds

\begin{tabular}{|c|l|c|c|c|c|}
\hline \multicolumn{1}{|c|}{ Methods } & Yes & No & $\begin{array}{c}\text { I don't } \\
\text { know }\end{array}$ & $\begin{array}{c}\text { Total } \\
(\%)\end{array}$ \\
\hline A & The best practices known & 53,45 & 5,17 & 41,38 & $\mathbf{1 0 0 , 0 0}$ \\
\hline B & $\begin{array}{l}\text { Thresholds used by the group (if the } \\
\text { company is part of a group) }\end{array}$ & 10,34 & 20,69 & 68,97 & $\mathbf{1 0 0 , 0 0}$ \\
\hline C & $\begin{array}{l}\text { Methods developed internally according to } \\
\text { the specific conditions }\end{array}$ & 50,00 & 10,34 & 39,66 & $\mathbf{1 0 0 , 0 0}$ \\
\hline
\end{tabular}

Question no. 10

How do you estimate materiality thresholds for audits of the financial statements (if you perform audits)?

Use of methods to estimate thresholds for audit

\begin{tabular}{|c|l|c|c|c|c|}
\hline & \multicolumn{1}{|c|}{ Methods } & Yes & No & $\begin{array}{c}\text { I don't } \\
\text { know }\end{array}$ & $\begin{array}{c}\text { Total } \\
(\%)\end{array}$ \\
\hline A & $\begin{array}{l}\text { By applying the best recommendations in } \\
\text { this field (best practice) }\end{array}$ & 56,90 & 1,72 & 41,38 & $\mathbf{1 0 0 , 0 0}$ \\
\hline B & $\begin{array}{l}\text { Threshold used by the group (if the } \\
\text { company is part of a group) }\end{array}$ & 13,79 & $\begin{array}{c}15,5 \\
2\end{array}$ & 70,69 & $\mathbf{1 0 0 , 0 0}$ \\
\hline C & Estimation models generated for each client & 50,00 & $\begin{array}{c}10,3 \\
4\end{array}$ & 39,66 & $\mathbf{1 0 0 , 0 0}$ \\
\hline D & Established by other specialists & 6,90 & $\begin{array}{c}17,2 \\
4\end{array}$ & 75,86 & $\mathbf{1 0 0 , 0 0}$ \\
\hline
\end{tabular}

Based on the results obtained (table 16) we note that auditors have approximately the same methods of establishing materiality thresholds as accountants, respectively based on good practice recommendations (57\%), but also on customer-specific methods. Financial auditors do not call on specialists in order to estimate audit materiality thresholds. The table does not show results obtained per auditors, experts, etc! 


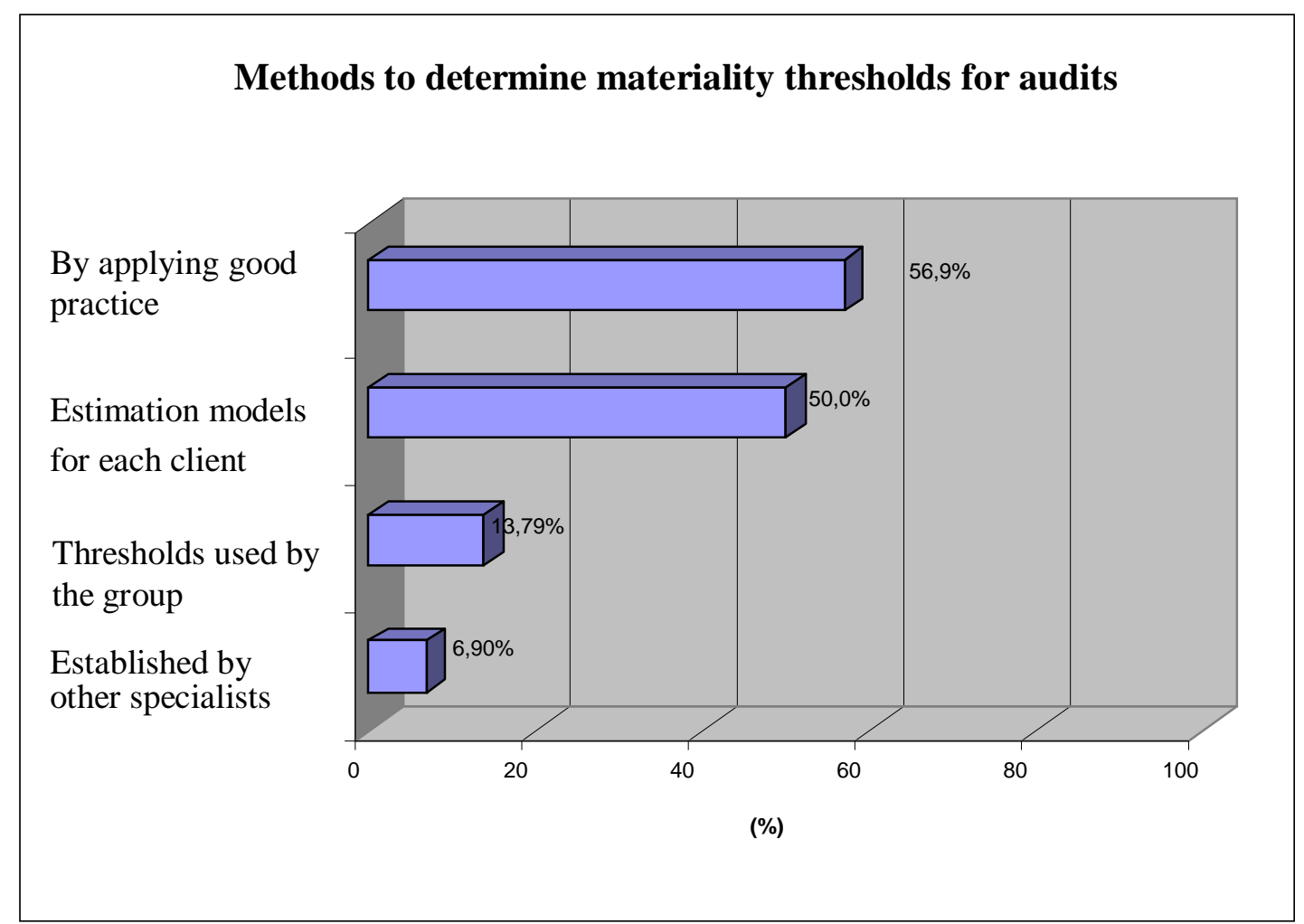

Fig. no. 11. - Methods to determine materiality thresholds for audits

\section{Conclusions}

The results of the survey allowed us a better assessment of the perception of estimation techniques in companies' activities. We were able to identify the practical difficulties of assessment through estimation techniques.

We have seen that the estimates are used partially to assess the financial position, especially at impairment of assets, provisions and lifetimes, most companies use estimation techniques in determining the fair value of tangible assets and goods received free of charge. In estimating lifetimes of depreciable assets, most companies turn to external assistance and for the estimating fair value, most companies use market value rather than the other techniques based on updated cash flows. Most companies base their investment and financing decisions on estimation techniques.

In order to assess their financial position companies don't make estimates in any situation based on the economic reality. In estimating lifetimes of depreciable assets they don't use either good practice models or their own model adapted to the specifics of each entity.

We conclude that the methods of assessing financial flows, the companies not often use the estimation methods based on updated cash flows, not all of the companies use estimates in determining net realisable value of inventories. In determining revenues and expenses for one financial year they don't use often the estimation techniques based on the cut-off principle. In estimating depreciation of assets and lifetimes not many companies use professional judgements based on economic content but all the time on tax criteria. In preparing revenues and expenses budgets a small number of companies use estimation techniques based on adjustment rates but rather the inflation indices. Company's estimates are not made through own efforts but in many cases with external assistance. Most companies don't often use estimation techniques to substantiate dividend decisions.

We would like to highlight that in addition to the responses to the questionnaire some of the respondents have sent us also their suggestions related to the practical problems encountered regarding estimates, such as: 
- development of practical guides covering methodologies applied at micro-level in terms of accounting, financial and audit estimates;

- professional training programmes to include more technical issues related to estimates;

- allocation of funds for the development at company level of special departments or structures to deal with estimation techniques, without the need for these to be undertaken by the financial-accounting department;

- development of procedures at company level, approved by management, including estimation techniques based on good practices;

- availability of software to allow implementation and preparation of estimates;

- audit professionals consider that the need to use estimation techniques is not sufficiently known by the business environment and solutions should be found to build a management culture in this respect.

\section{Further research}

Such research can be done by groups of entities, the first target being those entities applying International Financial Reporting Standards (IFRS), which require a complex estimation system in all areas covered.

The results of this analysis were forwarded to the academic environment (A.S.E. Bucharest) and to the Ministry of Public Finance - Department for accounting regulations, in order to be used in future investigations. The Ministry of Public Finance with the academic environment (ASE Bucharest) used the results of this analysis to make further investigations at the level of public entities that are considered by the government strategy for IFRS implementation. This time the sample consisted only of entities considered in the IFRS implementation programme (credit companies, insurance companies, listed entities).

Especially respondents in the accounting field consider that the technique for assessing fair value should interest much more the specialists in evaluation. The low percentage related to estimation of revenues and expenses is disturbing with respect to the users of financial statements, considering that the result of a year is determined as difference between revenues and expenses of the year, and if these are not determined properly it means that also the income statement is distorted.

\section{References}

1. Altman E. I., 1977, Some Estimation of the Cost of Lending Errors for Commercial Banks, Journal of Commercial Bank Lending.

2. Andenmatten A., 1995, Evaluation du risque de defaillance des emetteurs d'obligations : une approche par l'aide multicritere a la decision, Ed. Presses Polytechnique et Universitaires Romandes, Lausanne 1995

3. Barbu E., 2002, Calitatile intrinseci ale valorii juste puse sub semnul intrebarii, Revue Contabilitatea, expertiza si auditul afacerilor, no. 6

4. Bogdan V., Balaciu D., 2007, Revolution and reform in the Central and Easter European Countries After The Fall of Communism. Lessons For Romania, International Conference Competitiveness and European Integration, Cluj-Napoca, Romania, October 26-27,

5. Cambel I., Taylor J., 1972, Valuation of elusive assets, Canadian Chartered Accountant

6. Ciutac I., 2003, Analiza de senzitivitate. Concept si aplicatie in diagnosticul strategic al intreprinderii, These de doctorat, Academie de Sciences Economiques Bucarest - Romania

7. Dumitrache C.,,2002, Previziune economică, Bucureşti: Ed.Didactică şi Pedagogică.

8. Dumitrescu D., Dragota V., 2002, Ciobanu A. Evaluarea intreprinderilor, Editura Economica Bucarest

9. Epstein A., Ali M., 2005, Interpretarea si aplicarea Standardelor Internationale de Contabilitate si Raportare Financiara, Edition BMT Publishing House Bucarest 
10. Feleaga N., Malciu L., 2004, Recunoastere, evaluare si estimare in contabilitatea internationala, Edition du Corps des Experts Comptables et Comptables Agreges, Bucarest

11. Iordache E., 2007, Reguli de estimare a informațiilor din situațiile financiare, Bucure $\square$ ti: Revista Audit Financiar nr. 3, Camera Auditorilor Financiari.

12. Keasey K., Watson R., 1987, Non-financial symptoms and prediction of small company failure : A test of Argenti's Hypotheses, Journal of Business Finance and Accounting

13. Mihoc G., Urseanu V., 1994, Sondaje şi estimații statistice, Bucureşti: Editura Tehnică.

14. Pindyck R., Rubinfeld D., McGraw-Hill., 1998, Econometric Models and Economic Forecasts, Irwin.

15. Porojan D., 2006, Bazele sondajului, Bucuresti: Editura Irecson.

16. Zaman C., 1998, Econometrie, Bucureşti: Editura Pro Democrația.

17. www.iasb.org

18. www.cafr.ro

19. www.ifac.com 